\title{
PENGARUH MEDIA TOKER (TORSO KERTAS) TERHADAP PRESTASI BELAJAR SISWA MATERI SISTEM PERNAPASAN MANUSIA
}

\section{THE EFFECT OF MEDIA TOKER (PAPER TORSO) ON STUDENT'S LEARNING ACHIEVEMENT IN HUMAN RESPIRATORY SYSTEM MATERIALS}

\author{
Dede Tika $^{1 *}$, Moh.Fahmi Nugraha ${ }^{2}$, Anggia Suci Pratiwi ${ }^{3}$ \\ 1,2,3 Pendidikan Guru Sekolah Dasar Universitas Muhammadiyah Tasikmalaya, Indonesia \\ 'dedetika1998@gmail.com \\ 2m.fabminugraba@umtas.ac.id \\ 3anggia@umtas.ac.id
}

DOI: $10.35438 /$ cendekiawan.v3i2.194

\section{Article Info \\ Historical Articles Submitted: 2020-08-14 \\ Revised: 2021-12-14 \\ Issued: 2021-12-29}

Keywords: Media Toker (Paper Torso), Learning Achievement

Kata kunci: Media Toker (Torso Kertas), Prestasi Belajar

Abstract

\begin{abstract}
The purpose of this study is to determine the influence of the media (paper torso) for the students' learning performance of breathing system material in buman grade $V$ at SDN Cintawangi. This research includes research (quasi experimental design) using Pretest-Posttest design Nonequivalent control group design. The subject in this study is all students of the class $V$ elementary school Cintawangi totalling 20 students. Samples were taken in random sampling which resulted in 10 student grade experiments and 10 control class students. Data collection techniques using documentation, unstructured interviews and tests. Based on the results of the study obtained that by using the Toker media (paper torso) can affect the learning performance of the respiratory system students in buman class $V$ at SDN Cintawangi. It is also evident from the difference between the average learning achievement in the experimental class and the control class. The average value of an experimental class posttest of 89 is greater than that of the control class of 66.
\end{abstract}

\section{Abstrak}

Tujuan dalam penelitian ini yaitu untuk mengetahui pengaruh media toker terhadap prestasi belajar materi sistem pernapasan pada manusia kelas V di SDN Cintawangi. Penelitian ini termasuk penelitian (quasi eksperimen design) menggunakan desain Pretest-Posttest Nonequivalent control group design. Subjek dalam penelitian ini adalah seluruh siswa kelas V SD Negeri Cintawangi yang mengumpulkan 20 siswa. Sampel diambil secara random sampling yang menghasilkan 10 siswa kelas eksperimen dan 10 siswa kelas kontrol. Teknik pengumpulan data menggunakan dokumentasi, wawancara tidak terstruktur dan tes. Berdasarkan penelitian yang diperoleh bahwa dengan menggunakan media toker (torso kertas) dapat memengaruhi prestasi belajar siswa materi sistem pernapasan pada manusia kelas V di SDN Cintawangi. Hal ini juga terlihat dari perbedaan antara rata-rata prestasi belajar pada kelas eksperimen dan kelas kontrol. Nilai rata-rata posttest kelas eksperimen sebesar 89 lebih besar dari pada kelas kontrol yaitu sebesar 66 .

\section{PENDAHULUAN}

Kualitas dari pendidikan juga merupakan salah satu faktor yang menentukan kualitas sumber daya manusia itu sendiri. Menurut Arsana, Jampel dan Kusmariyatni (2017) "Pendidikan merupakan usaha manusia untuk memanusiakan manusia itu sendiri yaitu untuk membudayakan manusia." IPA merupakan proses yang digunakan untuk mempelajari suatu objek studi, menemukan, dan 
mengembangkan produk sains, dan sebagai aplikasi. Teori-teori IPA akan melahirkan teknologi yang dapat memberi kemudahan bagi kehidupan (Kusumaningrum dan Syachruroji, 2016). Menurut Ruth Luthfer dalam Tafonao (2018:103) mengatakan "media pembalajaran adalah salah satu alat bantu bagi guru untuk menyampaikan materi pelajaran, meningkatkan kreativitas siswa dan meningkatkan perhatian siswa dalam proses pembelajaran." Sedangkan media merupakan salah satu komponen komunikasi, yaitu sebagai pembawa pesan dari komunikator menuju komunikan (Criticos dalam Daryanto, 2016: 4). Proses belajar mengajar merupakan contoh proses komunikasi. Kegiatan belajar mengajar merupakan satu paket dengan media pembelajaran atau alat bantu belajar. Media pembelajaran berfungsi untuk membantu siswa dan guru dalam kegiatan belajar mengajar. Untuk guru lebih memudahkan dalam menyampaikan materi pembelajarannya sedangkan untuk siswa lebih mudah memahami materi yang disampaikan guru. Menurut Irmansyah (2015) mengatakan bahwa "Media pembelajaran adalah media yang sangat penting untuk mentransfer pengetahuan dan membantu siswa dalam memahami materi pelajaran." Media pembelajaran dapat mempertinggi proses dan hasil pembelajaran dengan taraf berfikir siswa. Media torso merupakan model berupa patung manusia yang dilengkapi dengan komponen organ-organ tubuh manusia, baik bentuk maupun letaknya. Menurut Kamus Besar Bahasa Indonesia dalam Rahmawati dan Julianto (2004: 3) mengatakan bahwa "media torso adalah patung batang tubuh tanpa lengan dan kaki Berdasarkan peneliti eksplorasi, ditemukan beberapa hal yang berkaitan dengan penelitian ini. Penelitian dari Firda Halawati (2019) dilaksanakannya penelitian ini bertujuan untuk mengetahui apakah terdapat pengaruh penggunaan media torso terhadap hasil belajar peserta didik pada mata pelajaran IPA di Sekolah Dasar Negeri Cikahuripan dan menunjukkan hasil bahwa terdapat pengaruh baik pada mata pelajaran IPA tentang sistem pencernaan manusia dengan menggunakan media torso untuk kelas eksperimen. Dan Penelitian dari Muhammad Isnaini, Indah Wigati dan Resti Oktari (2016) bertujuan untuk mengetahui bagaimana pengaruh penggunaan media pembelajaran batang tubuh terhadap hasil belajar siswa pada materi sitem pencernaan pada manusia di SMP Negeri 19 Palembang dan menunjukkan hasil bahwa terdapat pengaruh yang signifikan antara media pembelajaran batang tubuh terhadap hasil belajar. Penelitian diatas memiliki relevansi dengan penelitian ini, yaitu penggunaan media pembelajaran, tetapi dalam penelitian ini peneliti berasumsi untuk membuat media toker (torso kertas) yang dapat meningkatkan prestasi siswa dalam belajar.

Salah satu media pembelajaran adalah media pembelajaran toker (torso kertas). Media toker (torso kertas) merupakan media yang terbuat dari bubuk kertas yang diubah menjadi bubur kertas dan kemudian dibentuk menjadi sebuah media pembelajaran dengan styrofoam beralaskan yang dibentuk menyerupai anggota badan. Dalam pembuatan toker, diperlukan alat dan bahan yang cukup sederhana dan sering kita temukan dalam kehidupan sehari-hari. Adapun langkah pembuatannya seperti: gunting kertas bekas yang sudah dipotong-potong kecil, rendam selama satu jam, lalu diremas-remas menjadi bubur kertas, saring bubur-bubur kertas itu dengan kain yang benar-benar kering, lalu tunggu beberapa menit kemudian, sambil menunggu menunggu, buatlah pola anggota badan dan gambar sistem organ pernapasan manusia dari Styrofoam, buatlah lem dari tepung kanji, masukan tepung ke dalam air yang sudah disiapkan di ember, aduk hingga benar-benar rata, pasak menggunakan kuali dengan kompor dan aduk-aduk sampai membentuk lem tepung, bubur kertas yang sudah kering dengan lem tepung yang sudah jadi di campur dan aduk-aduk sampai rata, tempel di styrofoam yang telah kita buat pola anggota badan dan gambar sistem organ pernapasan manusia, lalu keringkan selama 1 hari, sebelum kering berikan cat warna dan keringkan lagi selama 1 hari, media toker (torso kertas) siap digunakan.

Media pembelajaran ini cocok digunakan untuk menyalurkan pengetahuan dari guru kepada peserta didik. Media ini termasuk media yang mudah untuk dibuat. Dengan menggunakan media pembelajaran ini pendidik dapat lebih memperjelas pesan agar tidak terlalu verbalitas dan juga dapat menimbulkan gairah belajar siswa, sehingga terjadinya interaksi langsung antara peserta didik dengan 
sumber belajar. Pemilihan media yang tepat diharapkan dapat meningkatkan prestasi belajar siswa. Menurut Djamarah dalam Pratiwi (2015:82) bahwa "prestasi belajar adalah hasil yang diperoleh berupa kesan-kesan yang mengakibatkan perubahan dalam diri individu sebagai hasil dari aktivitas belajar." Sedangkan, Menurut Hendrawan (2016) bahwa "prestasi belajar adalah hasil yang dicapai oleh siswa selama berlangsungnya proses belajar mengajar."

Berdasarkan hasil wawancara dengan Kiki Mariana, S.Pd, guru kelas V SD Negeri Cintawangi, masalah yang ditemui pada materi sistem pernapasan pada manusia dalam tema II subtema I pembelajaran 2, bahwa hasil ulangan pada tahun ajaran 2018/2019 masih rendah, hasil nilai rata-rata siswa yaitu 57 nilai tersebut tidak mencapai nilai standar KKM yaitu 61 dari 20 siswa terdapat 7 siswa (45\%) yang sudah tuntas dan 13 siswa (55\%) yang belum tuntas dan kegiatan belajarpun tidak menggunakan media pembelajaran.

Berdasarkan kondisi tersebut perlu adanya penggunaan media pembelajaran yang dapat melibatkan siswa aktif dan membantu peserta didik dalam meningkatkan prestasi belajar di kelas $\mathrm{V}$ di tahun ajaran berikutnya, pada tahun ajaran 2019/2020 tema II subtema 1 muatan IPA. Dalam hal ini, peneliti berasumsi bahwa media pembelajaran yang membuat siswa menjadi lebih aktif dan meningkatkan prestasi belajar pada tema II subtema I, maka perlu dilakukan penelitian tentang pengaruh media toker (torso kertas) terhadap prestasi belajar siswa materi sistem pernapasan pada manusia kelas V SDN Cintawangi.

\section{METODE}

Jenis penelitian ini adalah penelitian kuantitatif. Menurut Nana dan Herlina (2018:289) mengatakan bahwa penelitian kuantitatif adalah penelitian yang digunakan untuk meneliti populasi atau sampel tertentu, teknik pengambilan sampel pada umumnya dilakukan secara acak, pengumpulan data menggunakan instrumen penelitian, analisis data bersifat kuantitatif/statistik dengan tujuan untuk menguji hipotesis yang telah ditetapkan. Metode yang digunakan dalam penelitian ini menggunakan metode penelitian quasi eksperimen design. Dalam rancangan penelitian ini dengan membandingkan hasil pretest dan posttest dengan melibatkan kelompok eksperimen dan kelompok kontrol, dimana pengambilannya dilakukan secara acak. Menurut Sukmadinata (2017) bahwa "eksperimen kuasi bisa digunakan minimal kalau dapat mengontrol satu variabel saja meskipun dalam bentuk yang serasi, atau menjodohkan karakteristik, kalau bisa lebih baik." Desain penelitian yang digunakan dalam penelitian ini yaitu nonequivalent control group design. Kedua kelompok ini diberikan pretest terlebih dahulu. Setelah itu, kelompok eksperimen diberikan perlakuan (treatment) berupa media toker (torso kertas) sedangkan kelompok kontrol tidak mendapat perlakuan hanya menerapkan pembelajaran konvensional. Perlakuan yang diberikan sebanyak 3 kali. Setelah diberi perlakuan posttest. Sehingga dapat diperoleh nilai antara skor pretest dan posttest. Nilai pretest dan posttest akan mengetahui pengaruh penggunaan media terhadap prestasi belajar siswa materi sistem pernapasan pada manusia kelas V SD Negeri Cintawangi.

Penelitian ini dilakukan di SDN Cintawangi Desa Cintawangi Kecamatan Karangnunggal Kabupaten Tasikmalaya. Penelitian ini dimulai dari tanggal 14 Juli 2020 dengan memberikan pretest terlebih dahulu dan berakhir pada tanggal 28 Juli 2020 dengan posttest, dengan tiga kali perlakuan.

Populasi yang diambil dalam penelitian ini adalah seluruh siswa kelas V SD Negeri Cintawangi yang menerima 20 siswa. Sampel dalam penelitian ini diambil dari populasi terjangkau yaitu hanya pada siswa kelas V saja. Sampel 20 siswa dibagi menjadi dua kelas yang dilakukan secara acak tanpa memperhatikan strata yang ada pada populasi itu, yaitu dengan cara berhitung, 10 siswa yang menyebutkan angka ganjil sebagai kelas eksperimen dan 10 siswa yang menyebutkan angka genap sebagai kelas kontrol.

Menurut Alwan, Darmaji dan Hendri (2017) mengatakan bahwa "Data adalah bahan mentah yang perlu diolah untuk menghasilkan informasi atau keterangan yang menunjukkan fakta." Teknik 
pengumpulan data yang digunakan adalah dokumentasi, wawancara tidak terstruktur dan tes. Menurut Admizal dan Fitri (2018:168) menyatakan bahwa "teknik dokumentasi ini bertujuan untuk mempeoleh tambahan data dari data yang telah diperoleh." Teknik dokumentasi dalam penelitian ini yaitu berbagai data sekunder berupa hal-hal yang berkaitan dengan prestasi belajar siswa di SD Negeri Cintawangi, diantaranya profil sekolah, nilai pretest, posttest, dan foto-foto saat proses pembelajaran di kelas eksperimen dan di kelas kontrol. Menurut Prasanti (2018) mengatakan bahwa "Wawancara dilakukan untuk mengetahui dan melengkapi data upaya memperoleh data yang akurat dan sumber data yang tepat. Menurut Sugiyono (2016: 197) menyatakan bahwa "tidak terstruktur adalah wawancara di mana peneliti menggunakan pedoman wawancara yang disusun secara sistematis dan lengkap pengumpulan datanya." Jadi dalam penelitian disini menggunakan teknik wawancara tidak terstruktur (tidak membuat pedoman secara sistematis). Dalam penelitian ini tes yang digunakan adalah pretest dan posttest penggunaan media pembelajaran toker. Menurut Kadir (2015) "Tes merupakan suatu bentuk alat evaluasi untuk mengukur seberapa jauh tujuan pengajaran telah tercapai, yang berarti evaluasi terhadap hasil belajar." Tes ini akan dilakukan sebelum diberi perlakuan atau pretest. Hal yang serupa dilakukan pada posttest atau setelah diberi perlakuan. Teknik pengumpulan data ini digunakan untuk mengetahui pengaruh penggunaan media terhadap prestasi belajar siswa materi sistem pernapasan pada manusia kelas V SD Negeri Cintawangi.

Instrumen pengumpulan data yang digunakan berupa tes dalam bentuk soal pilihan ganda yang mengumpulkan 20 soal untuk pretest dan posttest. Untuk menguji validitas dapat dengan meminta pendapat ahli atau disebut expert judgement. Peneliti melakukan penilaian ahli terhadap instrumen penelitian berupa tentang sistem organ pernapasan pada manusia kepada ahli dibidang IPA dan guru sekolah dasar yaitu Moh. Fahmi Nugraha, M.Pd. dan Kiki Mariana, S.Pd. Instrumen dikatakan valid jika dapat mengungkapkan data dari variabel yang diteliti secara tepat. Karena tes yang digunakan berbentuk pilihan ganda. Adapun pengukuran validitas tiap butir soal pada penelitian ini menggunakan product moment dari Pearson dengan menggunakan SPSS versi 24.

Menurut Yusuf (2018:17) mengatakan bahwa "validitas instrument mempermasalahkan sejauh mana pengukuran

\section{HASIL PENELITIAN}

Penelitian ini dilakukan di SDN Cintawangi Desa Cintawangi Kecamatan Karangnunggal Kabupaten Tasikmalaya. Penelitian ini dimulai dari tanggal 14 Juli 2020 dengan memberikan pretest terlebih dahulu dan berakhir pada tanggal 28 Juli 2020 dengan posttest, dengan tiga kali perlakuan Pada eksperimen terlebih dahulu menyampaikan materi dan tujuan yang akan dicapai dalam setiap perlakuan. Dalam proses pembelajaran kegiatan awal dimulai pembelajaran seperti biasanya dimana guru melakukan apersepsi terlebih dahulu. Langkah penyampaian materi pada perlakuan ke satu menyampaikan materi pembelajaran dengan menggunakan media toker dan mengamati media keker dan memperhatikannya. Siswa melakukan tanya jawab mengenai materi yang belum Sulit setelah itu, peneliti memberikan soal dan siswa mengerjakan soal dan jawaban yang ditulis dibuku tugas masingmasing, lalu salah satu peserta didik maju kedepan untuk mengerjakannya dengan bantuan media toker. Kemudian pada perlakuan ke dua peneliti menyampaikan materi dengan menunjukan setiap nama organ pernapasan manusia dengan bantuan media pembelajaran. Peneliti membagi siswa menjadi 4 kelompok. Masing-masing dari kelompok diberikan nama-nama organ pernapasan manusia secara acak dan salah satu siswa dari 4 kelompok mampu mengerjakannya. Pada perlakuan ke tiga peneliti membagi siswa ke dalam 4 kelompok, siswa mampu mengerjakan soal-soal yang diberikan dengan menggunakan media toker secara bergantian. Peneliti memberi kesempatan untuk bertanya setelah itu, masing-masing dari kelompok kedepan memaparkan hasil pekerjaan dengan menggunakan media toker (torso kertas). 
Siswa begitu antusias untuk memahami materi pada saat itu, di akhir pembelajaran memberikan tes akhir untuk mengetahui sejauh mana siswa memahami pelajaran. Pada kelas eksperimen nilai tertinggi dari pretest 1 siswa 65, dalam proses belajar belajar menghargai meskipun hanya memperhatikan, sedangkan nilai paling rendah 30 hanya 1 siswa, hanya ada hafal dimana letak organ pernapasan manusia. Adapun hasil posttest yang diadakan setelah perlakuan, nilai tertinggi sebesar 100 hanya 1 siswa, kelebihannya siswa dalam menambahkan hasil belajarnya dan nilai terendahnya adalah 75 hanya 1 siswa, dalam pembelajaran kurang dan takut salah. Untuk lebih jelasnya bisa dilihat diagram pengaruh prestasi belajar siswa pada pretest dan posttest setelah dilakukanya pembelajaran, dapat kita lihat pada gambar 1 berikut ini:

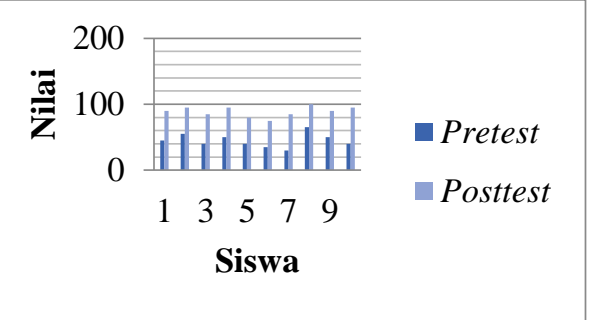

Gambar 1. Pengaruh pretest dan posttest di kelas eksperimen

Sedangkan kegiatan pembelajaran dengan menggunakan model konvensional (ceramah) di kelas kontrol peran siswa ini mendengarkan peneliti saat menjelaskan materi pernapasan pada manusia tema II pelajaran IPA, setelah itu diberi tentang materi yang telah diajarkan, kemudian siswa menyimpulkan pembelajaran. Setiap perlakuan pada kelas kontrol yaitu mengamati dan menggunakan gambar dari materi yang ada pada buku. Pada pretest nilai terendah sebesar 30 hanya 1 siswa, karena kurangnya minat belajar siswa dan yang mendapat nilai tertinggi adalah 60 hanya 1 siswa, dimana siswa tersebut selalu mengemukakan pendapat. Setelah diadakan 3 kali perlakuan maka selanjutnya diadakan tes akhir, tertinggi pada posttest 1 siswa sebesar 80, siswa telah menghafal organ pernapasan manusia dan nilai terendah adalah 50 menemukan 1 siswa, penyebab nilai rendah karena kurangnya motivasi belajar dalam mengikuti pembelajaran. Untuk lebih jelasnya dapat dilihat diagram pengaruh prestasi belajar siswa pada pretest sebelum pembelajaran dengan model konvensional dan posttest setelah dilakukanya pembelajaran, dapat kita lihat pada gambar 2 berikut ini:

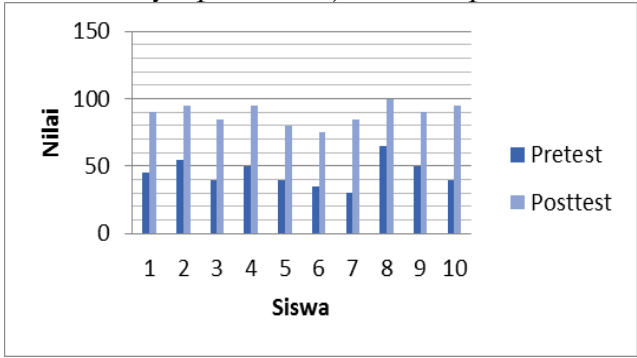

Gambar 2. Pengaruh pretest dan posttest di kelas kontrol

Menurut Ghozali dalam Ayuwardani (2018) mengatakan bahwa "Uji normalitas berfungsi untuk menguji apakah dalam sebuah model regresi, variabel pengganggu memiliki distribusi normal." Uji normalitas yang digunakan dalam penelitian ini adalah uji shapiro-wilk. Analisis data ini menggunakan SPSS versi 24. Uji normalitas dengan menggunakan uji Shapiro-Wilk pada uji normalitas pretest kelas eksperimen dengan nilai signifikansi 0,809 $>0,05$ dan pada kelas kontrol memiliki nilai signifikansi $0,633>0,05$ maka data tersebut berdistribusi normal. Sedangkan posttest kelas eksperimen memiliki nilai signifikansi 0,668 > 0,05 dan pada kelas kontrol memiliki nilai signifikansi 0,769>0,05 maka data tersebut berdistribusi normal. Setelah itu, dilanjutkan dengan menguji homogenitas dengan menggunakan uji ANAVA atau analysis of variance (anova). Menurut Priyanto dalam Amaliah (2017) mengatakan bahwa "jika nilai signifikan lebih besar dari 0,005 maka 
dapat dikatakan bahwa varian dari dua atau lebih kelompok adalah sama." Ketentuan uji homogenitas adalah jika sig $>0,05$ maka data bersifat homogen. Penghitungan uji homogenitas menggunakan SPSS versi 24. Hasil pengolahan data uji homogenitas dapat dilihat pada tabel 1 dan 2 berikut ini:

Tabel 1. Hasil Uji Homogenitas Pretest

\begin{tabular}{llll}
\hline Levene Statistic & df1 & df2 & Sig. \\
\hline .169 & 1 & 18 & .686 \\
\hline
\end{tabular}

Tabel 2. Hasil Uji Homogenitas Posttest

\begin{tabular}{llll}
\hline Levene Statistic & df1 & df2 & Sig. \\
\hline .162 & 1 & 18 & .692 \\
\hline
\end{tabular}

Tampilan output dapat dilihat pada tabel 1 dan 2, bahwa nilai signifikasi data nilai Pretest 686 yang berarti $>$ dari 0,05 dan signifikasi data nilai Posttest 692 yang berarti $>$ dari 0,05 maka Ho diterima, sehingga data dapat dijelaskan bersifat homogenitas. Menurut Samidi (2015) mengatakan bahwa "hipotesis merupakan jawaban sementara terhadap masalah yang menjadi objek dalam penelitian." Uji hipotesis yang dilakukan dalam penelitian ini adalah independent semple t-test. Menurut Qomari (2009) bahwa "Uji " $\mathrm{t}$ " independent sample (sampel dari kedua rata-rata yang hendak dibandingkan berasal dari sampel yang berbeda/ lain sampel." Uji ini dilakukan untuk mengambil keputusan apakah hipotesis diterima atau ditolak. Ketentuan uji hipotesis jika:

Ho : tidak terdapat pengaruh penggunaan media toker (torso kertas) terhadap prestasi belajar siswa materi sistem pernapasan pada manusia kelas V di SD Negeri Cintawangi.

$\mathrm{Ha}$ : terdapat pengaruh penggunaan media toker (torso kertas) terhadap prestasi belajar siswa materi sistem pernapasan pada manusia kelas V di SD Negeri Cintawangi.

Hasil output dengan menggunakan independent semple t-test pada program SPSS versi 24. Nilai signifikansi $0,692>0,05$ dan uji hipotesis dengan signifikasi (two tailed) $0,000<(0,05)$, itu artinya $\mathrm{H}_{\mathrm{o}}$ ditolak artinya $\mathrm{H}_{\mathrm{o}}$ ditolak dan $\mathrm{H}_{\mathrm{a}}$ diterima, dengan menggunakan bagian atas (equal variances assumed) yang berarti terdapat pengaruh penggunaan media toker (torso kertas) terhadap prestasi belajar siswa materi sistem pernapasan pada manusia kelas V di SD Negeri Cintawangi. Hal itu juga didukung oleh nilai rata-rata posttest kelas eksperimen sebesar 89 lebih besar dari pada kelas kontrol yaitu sebesar 66. Dapat disimpulkan berdasarkan hasil uji hipotesisi diatas maka penelitian ini terdapat pengaruh penggunaan media toker (torso kertas) terhadap prestasi belajar siswa materi sistem pernapasan pada manusia kelas V di SD Negeri Cintawangi.

\section{PEMBAHASAN}

Penelitian ini telah membuktikan bahwa media pembelajaran toker lebih baik dibandingkan model konvesional (ceramah) terhadap prestasi belajar siswa kelas V materi sistem pernapasan pada manusia SDN Cintawangi. Setelah dilakukan analisis, pada pretest di kelas kontrol dan dikelas eksperimen bahwa hasilnya tidak terlalu terdapat perbedaan karena terlihat dari masing-masing ratarata kelas tidak terlalu jauh perbedaannya yaitu pada kelas kontrol 42,5 dan pada kelas eksperimen 45. Sedangkan perbedaan rata-rata pada hasil posttest kelas kontrol mencapai 66 dan kelas eksperimen 89, sehingga peningkatanya sebesar 44\% $<23,5 \%$. Dengan demikian bahwa terdapat perbedaan rata-rata prestasi belajar siswa secara signifikasi pada posttest kelas kontrol dan kelas eksperimen. Hal itu juga disampaikan (Hendrawan \& Nugraha, 2020) bahwa hasil perhitungan pretes kelas control dan kelas eksperimen ada perbedaan. 
Keterbatasan dalam penelitian ini yaitu tempat dalam pelaksanaan pembelajarannya terbagi ke dalam beberapa kelompok dan tempatnya di luar area sekolah dan pelaksanaan pembelajarannya di rumah dan di madrasah. Hal ini dilakukan atas pertimbangan kepala sekolah karena keadaan yang belum stabil. Kelebihan selama penelitian yaitu siswa terlihat bersemangat dengan materi yang diajarkan dengan menggunakan media pembelajaran toker (torso kertas) dan siswapun ingin memiliki media toker tersebut karena tertarik dengan bahan dan alat yang digunakan dalam media tersebut.

Implikasi terhadap pelayanan dalam penelitian ini bagi siswa dengan menggunakan media pembelajaran toker (torso kertas) dapat meningkatkan prestasi belajar siswa tema II subtema I materi sistem pernapasan pada manusia muatan IPA. Implikasi terhadap pendidikan di penelitian ini menemukan pembelajaran yang besar untuk menciptakan suasana pembelajaran yang kondusif, banyak cara yang digunakan misalnya dengan menerapkan media pembelajaran toker (torso kertas) yang dapat dijadikan referensi untuk mata pelajaran IPA materi organ pernapasan manusia maupun materi organ tubuh manusia. Implikasi terhadap penelitian ini bahwa media pembelajaran toker (torso kertas) dapat dijadikan sebagai bahan acuan untuk mengadakan penelitian selanjutnya tetapi mungkin dari permasalahan yang berbeda seperti materi yang berbeda dalam upaya meningkatkan prestasi belajar siswa.

\section{SIMPULAN}

Berdasarkan hasil pengolahan dan analisa yang telah dilakukan dalam penelitian ini, bahwa penggunaan media pembelajaran toker (torso kertas) berpengaruh terhadap prestasi belajar siswa kela V materi sistem pernapasan pada manusia di SDN Cintawangi. Hal ini dibuktikan dari uji hipotesis dengan signifikasi (two tailed) $0,000<(0,05)$, itu artinya $\mathrm{H}_{\mathrm{o}}$ ditolak dan $\mathrm{H}_{\mathrm{a}}$ diterima. Hal itu juga didukung oleh nilai rata-rata posttest kelas eksperimen sebesar 89 lebih besar dari pada kelas kontrol yaitu sebesar 66 .

\section{REFERENSI}

Alwan., et. al. (2017). Faktor-Faktor Yang Mendorong Siswa MIA SMAN Mengikuti Bimbingan Belajar Luar Sekolah Di Kecamatan Telanaipura Kota Jambi. Jurnal EduFisika, Vol. 02, No. 01.

Amaliah, Rezeki. (2017). Hasil Belajar Biologi Materi Sistem Gerak Dengan Menerapkan Model Pembelajaran Kooperatif Tipe Rotating Trio Exchange (RTE) Pada Siswa Kelas Xi Sman 4 Bantimurung. Jurnal Dinamika. Vol.08 No.1, P-ISSN: 2087- 889 E-ISSN: 2503-4863.

Arsana, P., et. al. (2017). Pengaruh Model Pembelajaran Kooperatif Tipe Stad Berbantuan Peta Konsep Terhadap Hasil Belajar Ips Kelas IV SD. e-Journal PGSD Universitas Pendidikan Ganesha Mimbar PGSD. Vol: 5, No: 2.

Ayuwardani, Rizki, Primadita. (2018). Pengaruh Informasi Keuangan Dan Non Keuangan Terhadap Underpricing Harga Saham Pada Perusahaan Yang Melakukan Initial Public Offering. Jurnal Nominal. Volume VII, Nomor I.

Daryanto. (2016). Media Pembelajaran Peranan Sangat Penting Dalam Tujuan Pembelajaran. Jogjakarta: Gavamedia.

Halawati, Firda. (2019). Pengaruh Penggunaan Media Torso Terhadap Hasil Belajar Peserta Didik Pada Mata Pelajaran IPA. Jurnal Pendidikan Guru Madrasah Ibtidaiyah. Vol. 2 No. 1, 11-20.

Hendrawan, Budi. (2016). Hubungan Antara Pengelolaan Kondisi Sosio Emosional dan Prestasi Belajar Siswa Pada Pelajaran IPA Di Kelas Sekola Dasar. Naturalistic, Vol. 1 No. 1, 72-84. 
Hendrawan, B., \& Nugraha, M. F. (2020). The Influence Of Van Hiele's Theory On The Achievement Of Learning Materials Learning Class IV Elementary Schools. Cendekiawan, 2(2), 73-82.

Irmansyah, Fiki, Bagus. (2015). Efektivitas Media Pembelajaran Model Torso Terhadap Hasil Belajar Biologi Pada Siswa Kelas Viii SMP Negeri 1 Kalasan Yogyakarta. Jurnal Teknologi Pendidikan. Vol. IV, No. 2.

Isnaini, M., et. al. (2016). Pengaruh Penggunaan Media Pembelajaran Torso Terhadap Hasil Belajar Siswa Pada Materi Sistem Pencernaan Pada Manusia Di Smp Negeri 19 Palembang. Jurnal Biota. Vol. 2 No. 1.

Kadir, Abdul. (2015). Menyusun Dan Menganalisis Tes Hasil Belajar. Jurnal Al-Ta'dib. Vol. 8, No. 2.

Kusumaningrum, Citra N. \& Syachruroji, A. (2016). Perbedaan Hasil Belajar Kognitif Siswa Menggunakan Model Pembelajaran Kooperatif Tipe Make A Match Dan Ekspositori Pada Konsep Energi. JPSD. Vol. 2, No. 2. ISSN 2301-671X.

Nana, Darna., \& Herlina, Erlin. (2018). Memilih Metode Penelitian Yang Tepat: Bagi Penelitian Bidang Ilmu Manajemen. Jurnal Ekonologi Ilmu Manajemen. Volume 5, Nomor 1,P(Print)-Issn : 2355-6099, E(Online)-Issn : 2620-6188.

Prasanti, Ditha. (2018). Penggunaan Media Komunikasi Bagi Remaja Perempuan Dalam Pencarian Informasi Kesehatan. Jurnal Lontar. Vol. 6, No. 1.

Pratiwi, Noor, Komari. (2015). Pengaruh Tingkat Pendidikan, Perhatian Orang Tua, Dan Minat Belajar Siswa Terhadap Prestasi Belajar Bahasa Indonesia Siswa Smk Kesehatan Di Kota Tangerang. Jurnal Pujangga, Volume 1, Nomor 2.

Samidi. (2015). Pengaruh Strategi Pembelajaran Student Team Heroic Leadership Terhadap Kreativitas Belajar Matematika Pada Siswa SMP Negeri 29 Medan T.P 2013/ 2014. Jurnal EduTech. Vol 1, No 1.

Sugiyono. (2016). Metode Penelitian Pendidikan Pendekatan Kualitatif, Kuantitatif dan R\&D. Bandung: Alfabeta.

Sukmadinata, Nana, Syaodih. (2017). Metode Penelitian Pendidikan. Bandung: PT Remaja Rosdakarya.

Tafonao, Talizaro. (2018). Pe ranan Media Pembelajaran Dalam Meningkatkan Minat Belajar Mahasiswa. Jurnal Komunikasi Pendidikan, Vol.2 No.2, P-ISSN 2549-1725, E-ISSN 2549-4163.

Yusuf, Febrianawati. (2018). Uji Validitas dan Uji Reliabilitas Instrumen Penelitian Kuantitatif. Jumal Tarbiyah: Jurnal Ilmiah Kependidikan. Vol. 7 No. 1, p-ISSN: 2088-6991 e-ISSN: 2548-8376.

Rahmawati, Oktavia P \& Julianto. (2014). Penggunaan Media Torso Untuk Meningkatkan Hasil Belajar Siswa Di Sekolah Dasar. JPGSD.Volume 02, Nomor 02.

Qomari, Rohmad. (2009). Teknik Penelusuran Analisis Data Kuantitatif dalam Penelitian Kependidikan. Jurnal Pemikiran Alternatif Kependidikan. Vol. 14, No. 3. 